\title{
Preliminary Phytochemical Pharmacognostic Studies on the Different Source Plants of Kadamba
}

\section{Research article}

Anand Kumar $\mathbf{M ~ P}^{1^{*}}$, Srilakshmi $\mathbf{M}^{2}$

1. Reader \& H.O.D, 2. PG Scholar,

P.G, Dept of Dravyaguna, Dr.B.R.K.R.Govt. Ayurvedic College, Hyderabad.

\begin{abstract}
Ayurvedic Acharyas had a great knowledge of the medicinal plants because they used to live near the forests which are a good source of the natural resources. But now days due to urbanization, deforestation and industrialization certain medicinal plants have become extinct and became difficult to make use of them in therapeutics. Hence demand is naturally increased as there was restriction of entry into forests imposed to protect the endangering plants.

By increasing demand of such drugs which are considerably less in availability, by adulteration/substitution of the raw materials has taken its place creating havoc in the Ayurvedic pharmaceutical industry. Hence the need is to standardize these herbs through botanical surveys, Pharmacognostical studies, assessment of the quality material available in particular area of market etc.

In the present study of Anthocephalus cadamba MIQ (Kadamba), Adina Cordifolia BENTH \& HOOK (Dhara Kadamba), Mytragyna parvifolia KORTH (Dhuli Kadamba), for standardization collected from different places.
\end{abstract}

Keywords: Standardization, Biological assay, Nipa, Nighantu, H.P.T.L.C, NIN method

\section{Introduction:}

Kadamba is a plant drug that is widely used in many instances in the classical Ayurvedic texts for various ailments (1,2,3). Charaka mentioned Kadamba to be used as vegetable and fruit (4). Susrutha has described it in first group of sour fruits(5).

History of Kadamba can be traced back to Vedas, Puranas and Samhita. There is a reference of root and branches of Kadamba in different books of vedic period. It was used for dantadhavana. In

*Corresponding author:

\section{Dr. Philip Anand Kumar}

Reader \& H.O.D,

P.G, Dept of Dravyaguna,

Dr.B.R.K.R.Govt. Ayurvedic college,

Hyderabad.

E-mail: philipmudumala@gmail.com paraskara Guhyasutra 1/21, Atharva parishista 26/5/1-4, Yajna valkya shiksha 34, Manduki shiksha 4/1 etc., Kadamba has been mentioned. It is mentioned as Nipa in Panineeya Asthadhyayi, Pathanjali Mahabhashya, Gubhilagruhya sutra and Shulwa Prathishakhya.

Susrutha has mentioned Kadamba and Nipa as two different plants. But in most instances Kadamba and Nipa are used as synonyms(5).

In Ramayana while describing Chitrakuta, Nipa is mentioned one among the fruit bearing plants. In Mahabharata while describing Dwaitavana, Nipa and Kadamba are included among fruit bearing plants. There is mentioning of Kadamba tree in Srimad Bhagavata during the occasion of Kaliya mardana. It is also told that Lord Sri Krishna was very fond of this tree. Pathanjali in his Mahabhasya, 
mentions the Kadamba, while describing fruit varities. Kadamba was favourite tree of ancient India.

Inspite of the above history about the plant, the identity of the plant still remains a controversy, because many plants are being used as the source plants of Kadamba. Susrutha mentioned Kadamba and Nipa as two different plants. But latter in the nighantus, they are mentioned as the synonyms of the same plant. And different nighantus have mentioned different varieties of kadamba like Dhara Kadamba, Dhuli Kadamba, Bhoomi Kadamba Raja Kadamba etc. The source plants available for these include Anthocephalus cadamba MIQ., Adina Cordifolia BENTH \& HOOK., and Mytragyna parvifolia KORTH.

To evaluate the phytochemical similarities between these plants, a preliminary phytochemical study has been carried out on the above mentioned source plants of Kadamba.

\section{Pharmacognostic Study:}

The present Pharmacognostic study of Anthocephalus cadamba MIQ (Kadamba), Adinacordifolia BENTH \& HOOK (Dhara Kadamba) and Mytragyna parvifolia KORTH ( Dhuli Kadamba) includes the following.

1. Morphological Identification

2. Collection.

3. Powder Microscopic study.

4. Organoleptic properties.

5. Preliminary phytochemical analysis.

a. Determination of the moisture content

b. Total ash

c. Acid soluble ash

d. Water soluble ash

e. Alcohol soluble extract

f. Water soluble extract

g. Determination of PH

\section{Identification:}

The plants were identified properly by their morphological features and are compared with the standard literature available. The morphological features of the plants are as follows:

Anthocephalus cadamba MIQ., is a medium sized tree and is identified by its dark brown bark with irregular woody scales, elliptic - oblong leaves, small orange yellow coloured globose heads and globose pseudocarpic fruit.

Adina cordifolia BENTH \& $H O O K$., is a large decidious tree with dark grey bark with exfoliating in irregular woody scales, orbicular shortly acuminate leaves, Yellow flowers in globose pedunculate heads and dehiscent capsule.

Mytragyna parifolia KORTH., is also a large tree with light grey smooth exfoliating bark with elliptic leaves, greenish yellow fragrant flowers and an oblong capsule.

\section{Collection and processing:}

Leaves of the plants were collected and are shade dried and powdered. The powdered plant materials are used for the study.

\section{Powder microscopy studies: Materials and methods:}

The collected leaves of Anthocephalus cadamba MIQ, Adina Cordifolia BENTH \& HOOK and Mytragyna parvifolia KORTH., were fixed in 3:1 Alcohol: Acetic acid solution and kept for two days. After two days, the powder material is mounted on the glass slides and is studied under compound microscope at different magnifications and the following were observed.

\section{Powder microscopy of Anthocephalus cadamba:}

Isolated fragments of uniseriate conical hairs either whole or broken are found. Few, whole unicellular conical hairs, pieces of epidermis of lower surface with wavy anti clinical walls and stomata, few pieces of isolated stomata and prismatic crystal of calcium oxalate are found in the microscopy. 
Powder microscopy of Mitragyna parviflora:

Pieces of tracheary tissue with vessels and tracheary tissue with helical, calceiform and pitted walls were found in the microscopy. Pieces of translucent resinous masses, few, isolated sphaero raphides of various sizes, pieces of epidermis with parasitic stomata are also found in the microscopic study.

Powder microscopy of Adina Cordifolia:
Pieces of broken tracheary tissue with calciform, reticulate and broadened pitted elements with attached fibres and parenchyma, some pieces of parenchyma with polygonal to rounded cells with intercellular spaces, few translucent resinous droplets appearing are found in the microscopic study of Adina cordifolia.

\section{Organoleptic characters:}

It involved the identification of the colour, touch, odour and taste. The results are as follows:

\begin{tabular}{|l|l|l|l|l|}
\hline Samples & Colour & Touch & Odour & Taste \\
\hline Adina cordifolia & Green & $\begin{array}{l}\text { Slightly } \\
\text { coarse. }\end{array}$ & $\begin{array}{l}\text { Slightly pungent, } \\
\text { causes choking. }\end{array}$ & Bitter \\
\hline $\begin{array}{l}\text { Mitragyna } \\
\text { parvifolia }\end{array}$ & $\begin{array}{l}\text { Moss } \\
\text { green }\end{array}$ & $\begin{array}{l}\text { Slightly } \\
\text { coarse }\end{array}$ & Not characteristic. & $\begin{array}{l}\text { Slightly Bitter, } \\
\text { Astringent. causes } \\
\text { Anthocephalus } \\
\text { cadamba }\end{array}$ \\
\hline
\end{tabular}

\section{Physico-Chemical Analysis:}

\section{Determination of moisture content:}

Method:

2 gms of sample is taken in a previously weighted Petri plates. Petri plates with the samples were kept in the oven and maintained at $110^{\circ} \mathrm{c}$ for drying. After 3 hrs Petri plates were taken out weight was noted down. This procedure is repeated for 4-5 times until the constant weight is reached.

$\%$ of moisture $=$ difference in weight / weight of the sample X 100

\section{Result:}

Anthocephalus cadamba

Adina cordifolia

$4.0 \% \mathrm{~W} / \mathrm{W}$

Mytragyna parvifolia

$3.0 \% \mathrm{~W} / \mathrm{W}$

$1.25 \% \mathrm{~W} / \mathrm{W}$

Total Ash:

Method:

2 gms of each powder is taken in 3 heated silica dishes to avoid any moisture content. The materials are ignited to $100^{\circ}$ $150^{\circ} \mathrm{C}$ in an electric ignition till the charring of the drug material. Then it is kept in an incinerator at $50^{\circ} \mathrm{C}$, temperature allowed to roll back to Zero; then it is removed from furnace and cooled in a desiccators to room temperature and weighed.

Total ash $=$ weight of residue / weight of the sample X 100

Result:

$\begin{array}{ll}\text { Anthocephlus cadamba } & 5.0 \% \mathrm{~W} / \mathrm{W} \\ \text { Adina cordifolia } & 5.45 \% \mathrm{~W} / \mathrm{W} \\ \text { Mytragna parvifolia } & 7.5 \% \mathrm{~W} / \mathrm{W}\end{array}$

Acid Insoluble Ash Estimation: Method:

The total ash, which was obtained was boiled for 5 minutes with $25 \mathrm{ml}$ of diluted hydrochloric acid, collect the insoluble matter in a ash less filter paper, wash with hot water and ignited to constant heat. $\%$ of acid insoluble ash $=$ difference in weight / weight of sample X 100

Result:

Anthocephlus cadamba

$1.50 \% \mathrm{~W} / \mathrm{W}$ 
Adina cordifolia

Mytragna parvifolia

$0.65 \% W / W$

$1.5 \% \mathrm{~W} / \mathrm{W}$

Water Soluble Ash:

Method:

The total ash, which was obtained, was boiled for 5 minutes with $25 \mathrm{ml}$ of water. Collect insoluble matter in Gooch crucible or on an ash less filter paper, wash with hot water and ignite it for 15 minutes at a temperature not exceeding $450^{\circ} \mathrm{C}$.

Water soluble ash=Weight of total ashweight of insoluble matter

$\%$ of water soluble ash=Difference in weight /weight of sample $\boldsymbol{x} 100$

\section{Result:}

Anthocephlus cadamba

$1.0 \% \mathrm{~W} / \mathrm{W}$

Adina cordifolia

$2.18 \% \mathrm{~W} / \mathrm{W}$

Mytragna parvifolia

$1.5 \% \mathrm{w} / \mathrm{w}$

\section{Alcohol Soluble Extract: \\ Method:}

5 gm powder was taken in a volumetric flask, $100 \mathrm{ml}$ of alcohol was added to it and flask was kept for $24 \mathrm{hrs}$. The solution was filtered next day and 25 $\mathrm{ml}$ of this filtrate was evaporated in a previously weighed evaporating dish on a water bath. Later it was dried in the oven at $110 \mathrm{C}$ to remove the traces of alcohol. Constant weight was noted down.

$\%$ alcohol soluble extractive $=$ difference in weight / weight of the sample X 100

\section{Result:}

Anthocephlus cadamba

$20.0 \% \mathrm{~W} / \mathrm{W}$

Adina cordifolia

$12.0 \% \mathrm{~W} / \mathrm{W}$

Mytragna parvifolia

$16.0 \% \mathrm{w} / \mathrm{w}$

\section{Water soluble extract: \\ Method:}

$5 \mathrm{gm}$ powder was taken in a volumetric flask few drops of chloroform and subsequently $100 \mathrm{ml}$ of distilled water was added to it. It was kept for $24 \mathrm{hrs,} \mathrm{shaking}$ frequently for the first $6 \mathrm{hrs}$. next day the solution was filtered and $25 \mathrm{ml}$ of this filtrate was evaporated in a previously weighed evaporating dish on a water bath. Later it was dried in the oven at $110 \mathrm{C}$ to remove the traces of water. Constant weights were noted.

$\%$ of water soluble extractive $=$ Difference in weight /weight of sample x100

\section{Result:}

Anthocephlus cadamba

$10.0 \% \mathrm{~W} / \mathrm{W}$

Adina cordifolia

$10.0 \% \mathrm{~W} / \mathrm{W}$

Mytragna parvifolia

$14.0 \% \mathrm{w} / \mathrm{w}$

\section{Determination of pH:}

The determination of $\mathrm{p}^{\mathrm{H}}$ was carried out at room temparature of $25^{\circ} \mathrm{c}$. Calibration of the apparatus was done using buffer solution to $\mathrm{pH} 7$ water soluble and alcohol soluble solutions was kept ready, then the electrodes were immersed in both the solutions and readings were recorded. The results are as follows:

\begin{tabular}{|l|l|l|}
\hline SAMPLES & Ph alcohol & $\begin{array}{l}\text { Ph } \\
\text { Water }\end{array}$ \\
\hline $\begin{array}{l}\text { Anthocephlus } \\
\text { cadamba }\end{array}$ & 5.46 & 4.34 \\
\hline Adina cordifolia & 5.63 & 4.53 \\
\hline $\begin{array}{l}\text { Mytragna } \\
\text { parvifolia }\end{array}$ & 4.87 & 4.26 \\
\hline
\end{tabular}

\section{HPTLC:}

HPTLC was performed to develop phytochemical finger printing. It was performed using $10 \times 10 \mathrm{~cm}$ silica gel 60 F254 precoated HPTLC plates [MERCK, Germany]. $10 \mu \mathrm{l}$ Volume of each extract was applied on plates with the help of Camag linomat - 5 applicator [CAMAG, Switzerland] fitted with $100 \mu$ l Hamilton micro syringe. The chromatograms were developed at room temperature in a $10 \mathrm{x}$ $10 \mathrm{~cm}$ twin trough chamber using solvent systems Toluene:Ethyl acetate in a ratio of 6:4 for the etanolic extract of Anthocephalus cadamba MIQ, Adinacoordifolia BENTH \& HOOK, and Mitragyna parvifolia KORTH, respectively. 
After the development chromatograms of saponin were derivatized with $20 \%$ Antimony trichloride in chloroform in a ratio of $20: 100 \mathrm{ml}$ followed by heating at $110^{\circ} \mathrm{c}$ in preheated oven for $10 \mathrm{~min}$. These chromatograms were scanned and evaluated under wave lengths of $254 \mathrm{~nm} \& 366 \mathrm{~nm}$ using a camag TLC scanner [CAMAG Switzerland] to get graphical representation of finger prints.

From the HPTLC finger printing of the three drugs, presence of the saponins as the principle chemical compounds were identified.

\section{U.V.Visible spectrophotometer: Preparation of sample}

$5 \mathrm{gm}$ of powder of each viz. Anthocephalus cadamba MIQ, Adina cardifolia BENTH and HOOK and Mitragyna parvifolia KORTH were extracted with 100ml Methanol. From the filtrate $3 \mathrm{ml}$ of extract is treated with charcoal and centrifuged.

\section{Scanning of extract:}

$50 \mu \mathrm{l}$ of Anthocephalus cadamba MIQ and Adina cardifolia BENTH AND HOOK diluted to $3 \mathrm{ml}$ with Methanol, while $150 \mu \mathrm{l}$ Mitragyna parvifolia was diluted to $3 \mathrm{ml}$ with Methanol. The above extracts were scanned in the U.V.Visible region i.e 190-700nm using methanol as a plank solution by using Sphectronic Unicam Helios Spectrophotometer.

It is evident from the UV graph that the Anthocephalus cadamba MIQ has revealed 4 peaks at wave lengths of 230nm, 235nm, $282 \mathrm{~nm}$ and 324-329nm.

$$
\text { Mytragyna parvifolia KORTH }
$$
exhibits 3 peaks $324 \mathrm{~nm}-329 \mathrm{~nm}$ and

Adina Cordifolia BENTH \&

HOOK exhibited 2 peaks between 230$235 \mathrm{~nm}$ and $324-329 \mathrm{~nm}$.

This shows that the peaks obtained at $324 \mathrm{~nm}$ to $329 \mathrm{~nm}$ correspond to the same chemical content in all the three specimens.

\section{DISCUSSION:}

Kadamba has synonyms such as Kadanbarya, Nipa, Pavrishenya, Kalambaha, Pulaki, Priyaka etc. all these indicates that the tree bears fruits which are sour taste which produces horripilation. Flowers are beautiful which attract people by its fragrance, also blossoms during rainy season, are the specific characters of Kadamba. In other words resembling on the characters the homonym names were also given to Dhara Kadamba. Since Kadamba and Dhara Kadamba bears synonyms and also morphologically similar characters in some aspects, such as yellowish orange round flowers with sweet fragrance, fruits which are spear shaped, also flower blossoms during rainy season. All these indicate Dhara Kadamba is a variety of Kadamba.

Physic chemical study of the powder of the 3 drugs have been carried out and it was found that Mytragna parvifolia KORTH is having higher total ash, acid insoluble ash and water soluble extractive in comparison to other 2 varieties, while Anthocephalus cadamba $M I Q$ showed higher moisture content and alcohol soluble extractive. Adina Cordifolia BENTH \& HOOK has higher water soluble ash.

U.V.Visible spectrophotometer of extracts of 3 varieties of Kadamba exhibited that the peaks obtained at $324 \mathrm{~nm}$ to $329 \mathrm{~nm}$ correspond to the same chemical content in all the three specimens.

HPTLC studies revealed that the samples contained saponins as the main chemical contents.

\section{Conclusion:}

From the preliminary phyto chemical study it can be concluded that the three drugs being used as the source plants of the Kadamba are having some similarity in the phytochemical properties. As the study is only a preliminary work 
further phytochemical and clinical analysis of the drugs have to be done to know the proper identity of the drug.

\section{References}

1) P.V.Sharma,Dravya guna Vol-II, Chaukambha bharath academy 2009, Pg No.41.

2) P.V.Sharma,"Kaiyadeva Nighantu" 1978, Chaukambha orientalia, Varanasi, Pg No 958.

3) Shakti M. Gupta, Plant Myths \& Traditions in India, 1991, New Delhi, $2^{\text {nd }}$ edition, Munshiram Manoharlal Publishers Pvt Ltd, $17 \mathrm{p}$.

4) G.S. Pandey \& K.C.Chunekar, Bhavaprakasha Nighantu, 2009 Chaukambha Bharathi Academy Varanasi Pg No 496.

5) Kashi nath Sastri, Charaka Samhitha vol-I vol-II 1962, Chaukambha Sanskrit Samsthan, Varanasi, sutra sthana 4/23,17/108.4/47.

6) Kaviraj Ambika Datta, Susrutha Samhitha vol-I,\& vol-II 1993,
Chaukambha Vidya Bhavan Varanasi Sutra sthana 46/158.

7) Srikantha Murthy, Ashtanga Hridaya, vol-I\& II 1992, Chaukambha Sanskrit series, Varanasi.

8) Nadakarni. K.M., Indian Materia Medica vol-I 1982, Popular prakashan Pvt Ltd.

9) Kirthikar.K.R. \& Basu. B.D., "Indian Medicinal Plants" vol-II, 1975, Periodical experts, New Delhi, Pg.No-1250-1254.

10) Asima Chatterjee \& Satyesh Chandra, The treatise on the medicinal plants vol-V, 1997, CSIR, New Delhi, Pg.No 74, 75.

11) S.Raghgunath Iyer, "Indian medicinal plants (A compendium of 500 species) vol-IV, 1997, Orient longman,PgNo 120.

12) R.N.Nayar \& I.C.Chopra, Glossary of Indian medicinal plants 1956, 1986, CSIR, New Delhi,

13) C.D-Camy HPTLC Information.

14) Anand. Instrumental methods of analysis Willard, Meritt, Dean, Setlte. 